\title{
Efek Pengungkapan Pos Berbayar di Instagram Terhadap Intensi Membeli dan Preferensi Produk
}

\author{
Nuriyah Amalia* \& Laras Sekarasih \\ Fakutas Psikologi, Universitas Indonesia, Depok
}

\begin{abstract}
Abstrak
Sebagai dampak dari pembaruan ketentuan penggunaan Instagram, kini pos Instagram yang diunggah atas dasar afiliasi bisnis dengan sebuah merek diharuskan menyertakan disclosure language berupa keterangan "paid partnership" di bagian atas pos. Keterangan ini diprediksi dapat melemahkan intensi membeli dan preferensi konsumen terhadap produk yang diiklankan. Efek ini pun diprediksi akan diperkuat oleh kemampun individu dalam merekognisi iklan, tetapi dilemahkan oleh pengalaman individu menggunakan produk dari merek yang sama dengan produk dalam iklan. Untuk menjawab prediksi ini, peneliti melaksanakan sebuah studi eksperimental dengan dua variasi kelompok IV (pos Instagram berbayar dengan disclosure language vs tanpa disclosure language) yang melibatkan 312 partisipan. Kemampuan rekognisi iklan dan pengalaman menggunakan merek diposisikan sebagai moderator. Sesuai prediksi, keterangan paid partnership berdampak negatif terhadap intensi membeli, tetapi tidak terbukti mempengaruhi preferensi produk. Sementara itu, bertentangan dengan prediksi, kemampuan rekognisi iklan justru memperkuat intensi membeli individu setelah melihat pos Instagram dengan DL. Namun, kemampuan rekognisi iklan memang mampu melemahkan preferensi individu terhadap produk setelah melihat iklan dengan DL. Pengalaman menggunakan produk dari suatu merek terbukti mampu menimbulkan intensi membeli dan preferensi konsumen yang lebih kuat terhadap produk lain dari merek yang sama.
\end{abstract}

Kata kunci: disclosure language, rekognisi iklan, intensi membeli, preferensi produk, Instagram

\begin{abstract}
As the consequence of the platform's update on their terms of use, Instagram posts that are affiliated with business or brand are now required to label the posts explicitly as "paid partnership." Such disclaimer label might weaken purchase intentions and consumer preferences for product advertised. The effect of paid partnership disclaimer on intention to purchase might also depend on consumers' ability to recognize commercial messages as well as their previous experience with the brand. To answer the dynamic among the presence of paid partnership disclaimer, commercial message recognition, and previous experience with the brand on consumers' intention to purchase, a single factor (with 2 levels [paid Instagram post with disclosure language vs. no disclosure language]) experimental study with advertising recognition ability and brand experience as moderators was conducted $(n=312)$. As predicted, paid partnership label had negative impact on intention to purchase, but did not affect product preferences. Contrary to the hypothesis, ad recognition ability strengthened purchase intention for individual who saw paid Instagram posts with disclosure language. Advertising recognition ability indeed weakened consumers' preference for the marketed product among individuals who saw paid Instagram posts with disclosure language. Brand experience had positive impact on purchase intention and product preferences.
\end{abstract}

Keywords: marketing disclosure, advertising recognition, intention to purchase, products preferences, Instagram

\section{Pendahuluan}

Usaha mempersuasi senantiasa dilakukan produsen untuk mempengaruhi intensi membeli (IM) konsumen serta preferensi mereka terhadap suatu produk. Intensi membeli didefinisikan sebagai rencana yang secara sadar dibuat oleh konsumen untuk membeli suatu produk (Spears \& Singh, 2004), sedangkan preferensi produk (PP) adalah kecenderungan konsumen memilih satu produk dibanding produk lainnya karena produk tersebut dianggap mewakili diri idealnya (Jamal \& Goode, 2001; Sirgy, 2015). Intensi membeli dan PP tidak selalu berjalan beriringan; konsumen bisa saja 
memiliki preferensi terhadap suatu produk tanpa diiringi intensi untuk membelinya dan begitu pula sebaliknya (Sirgy, 2015).

Meski tidak selalu selaras, baik IM maupun PP dapat ditingkatkan dengan melibatkan selebritas dalam mempromosikan produk, terutama produk baru (Fang \& Jiang, 2015; Pornpitakpan, 2003). Bentuk promosi produk yang dilakukan selebritas bervariasi bentuknya, tetapi bentuk promosi yang paling umum dilakukan di era digital seperti saat ini adalah dengan membuat konten di media sosial (Lu, Chang, \& Chang, 2014; Pornpitakpan, 2003; Silvera \& Austad, 2003).

Salah satu platform media sosial yang kerap menjadi tempat untuk beriklan dengan melibatkan selebritas adalah Instagram. Iklan di Instagram bahkan menjadi salah satu yang paling berpengaruh di Indonesia dalam mempengaruhi keputusan konsumen untuk berbelanja secara daring (Priambada, 2016). Jenis selebritas yang membuat iklan di Instagram efektif mempengaruhi IM dan PP bukanlah selebritas tradisional, melainkan selebritas mikro (Djafarova \& Rushworth, 2017). Selebritas mikro memiliki citranya sendiri di media sosial untuk menarik perhatian pengikut berjumlah besar (Chae, 2017; Djafarova \& Rushworth, 2017; Evans, Phua, Lim, \& Jun, 2017). Dilibatkannya sosok selebritas mikro - atau di Indonesia lazim disebut sebagai "selebgram" - dalam mempromosikan produk menjadi masuk akal sebab selebgram dianggap lebih dapat dipercaya dan memiliki kehidupan yang lebih relevan dengan konsumen kebanyakan jika dibandingkan dengan selebritas tradisional, seperti penyanyi atau aktris (Djafarova \& Rushworth, 2017). Barang-barang yang dipromosikan selebgram pun dianggap lebih terjangkau oleh konsumen daripada barang yang dipromosikan selebritas tradisional sehingga lebih mungkin dimiliki (Djafarova \& Rushworth, 2017).

Dengan melibatkan selebgram, produsen umumnya membuat iklan berjenis tie-in advertisement yang diwujudkan dalam pos Instagram berbayar (PIB), yakni produk yang diiklankan dilibatkan dalam konten Instagram selebgram, layaknya review produk, sehingga sebuah iklan tersamar keberadaannya (Amornpashara, Rompoo, \& Phadoongsitthi, 2015). Bentuk iklan seperti ini dapat meningkatkan IM karena konsumen menyimpulkan bahwa selebritas benar-benar menyukai produk (Lu dkk., 2014; Silvera \& Austad, 2003). Meski menguntungkan bagi selebgram dan pengiklan, keberadaan PIB dapat merugikan konsumen. Federal Trade Commission (FTC), yaitu badan perlindungan konsumen di Amerika Serikat, menganggap PIB berpotensi memanipulasi konsumen karena terkamuflase dalam bentuk review produk sehingga FTC secara formal memperingatkan para selebritas untuk memberikan informasi kemitraan dalam PIB mereka (Spangler, 2017).

Peringatan FTC terhadap para selebritas memicu Instagram memperbarui kebijakannya (Spangler, 2017). Untuk mempermudah pemberitahuan kemitraan dalam pos Instagram, Instagram menyediakan fitur "paid partnership" yang dapat dicantumkan di bagian atas foto. Dalam ketentuan penggunaannya, Instagram menyebutkan bahwa pengguna Instagram wajib mencantumkan keterangan paid partnership dalam PIB (Instagram, nd). Dengan munculnya ketentuan baru ini, apakah pos Instagram berbayar yang melibatkan selebgram tetap efektif mempersuasi konsumen?

\section{Disclosure Language}

Keterangan paid partnership adalah contoh dari disclosure language (DL). Disclosure language dibutuhkan dalam konten persuasi yang tersirat, seperti review produk, untuk membantu konsumen dalam membedakan konten iklan dengan konten bukan iklan dengan harapan konsumen akan lebih resisten terhadap pengaruh persuasi (Campbell, Mohr, \& Verlegh, 2013; Boerman, van Reijmersdal, \& Neijens, 2014; van Reijmersdal dkk., 2016). Resistensi konsumen terhadap konten persuasi karena keberadaan DL terjadi melalui mekanisme psychological reactance (PR) (Brehm, 1993). Konsep PR berangkat dari premis bahwa setiap individu percaya akan kebebasan dalam memilih. Ketika seseorang tahu bahwa kebebasannya sedang terancam, ia akan termotivasi untuk menolak persuasi dari pihak lain (Brehm, 1993).

Konten persuasi dengan DL eksplisit, seperti "disponsori oleh", "iklan”, dan "iklan berbayar", akan dimaknai sebagai konten yang coba mempengaruhi keputusan konsumen hingga dianggap mengancam kebebasan (Miller, Lane, Deatrick, Young, \& Potts, 2007; Quick \& Stephenson, 2007; Wojdynski \& Evans, 2015). Dengan demikian, ketimbang menuruti persuasi yang muncul dalam konten, konsumen justru resisten terhadap persuasi tersebut (van Reijmersdal dkk., 2016). Penelitian Evans dkk. (2017) pun menunjukkan bahwa DL eksplisit dalam pos Instagram seperti hashtag \#PaidAd membuat konsumen lebih mudah mengenali konten persuasi sebagai iklan hingga akhirnya melemahkan intensi membeli konsumen. Hal senada ditunjukkan oleh studi de Veirman dan Hudders (2019) yang menyatakan bahwa keberadaan DL dalam pos berbayar selebritas mikro membuat konsumen lebih tidak menyukai produk yang diiklankan.

Namun, argumen berbeda disampaikan oleh Wright, Friestad, dan Boush (2005). Wright dan kolega menyampaikan bahwa keberadaan DL dalam iklan justru membuat konsumen anak-anak tidak skeptis terhadap iklan hingga tidak lagi waspada terhadap usaha desepsi iklan. Dampaknya, konsumen akan lebih ingin membeli produk yang diiklankan. Pernyataan ini didukung oleh hasil studi de Jans, Cauberghe, dan Hudders (2018) yang menunjukkan bahwa keberadaan DL dalam konten persuasi yang bersifat edukatif, misalnya konten layanan masyarakat, justru dapat meningkatkan penilaian positif konsumen terhadap persuasi. 
Hal yang perlu dicermati dari pernyataan Wright dkk. (2005) adalah fokus studi mereka, yakni anak-anak. Ketidakwaspadaan konsumen terhadap desepsi setelah melihat DL belum tentu terjadi pada orang dewasa. Orang dewasa memiliki regulasi dan kontrol diri yang dapat membuatnya resisten terhadap iklan dengan DL, terutama bila DL bersifat eksplisit dan disampaikan sebelum konten persuasi muncul (Janssen, Fennis, \& Pruyn, 2016; van Reijmersdal dkk., 2016; Wojdynski \& Evans, 2015). Keterangan "paid partnership" sebagai DL yang akan diterapkan secara baku oleh Instagram memenuhi dua kriteria tadi. Paid partnership akan selalu disampaikan sebelum konten persuasi muncul, yakni di bagian atas pos, dan secara eksplisit menyatakan bahwa konten di bawahnya dibuat berdasarkan kemitraan berbayar dengan merek tertentu. Konten persuasi yang diujikan dalam penelitian ini pun bukanlah iklan layanan masyarakat seperti stimulus dalam studi de Jans dkk. (2018). Dengan demikian, peneliti menduga keberadaan DL justru berpengaruh negatif terhadap intensi membeli dan preferensi produk seperti yang ditunjukkan oleh studi Evans dkk. (2017) serta de Veirman dan Hudders (2019).

Pengaruh DL paid partnership dalam pos Instagram terhadap IM dan PP penting untuk diteliti karena bentuk DL ini akan secara baku diterapkan oleh Instagram untuk penggunanya, sedangkan bentuk DL dalam Instagram yang diujikan oleh penelitian sebelumnya terbatas pada hashtag (Evans dkk., 2017) dan caption (de Veirman \& Hudders, 2019) yang notabene diletakkan setelah konten persuasi (foto). Padahal, paid partnership akan selalu diletakkan sebelum konten persuasi. Berdasarkan studi Boerman dkk. (2014), posisi DL sebelum konten persuasi membuat konsumen lebih resisten terhadap iklan. Bila DL paid partnership terbukti berpengaruh negatif terhadap IM dan PP, hal ini juga dapat menjadi masukan bagi pemerintah Indonesia untuk mewajibkan selebgram menggunakan label ini dalam pos berbayarnya karena Undang-Undang Perlindungan Konsumen No. 8 Tahun 1999 belum mewajibkan pengiklan untuk mencantumkan DL dalam konten persuasi (YLKI, 2015). Peneliti mengajukan hipotesis sebagai berikut.

Hipotesis 1a. Pos Instagram berbayar selebgram dengan disclosure language (DL) akan berpengaruh negatif terhadap intensi membeli. Individu yang melihat pos Instagram dengan DL akan melaporkan intensi membeli yang lebih rendah.

Hipotesis 1b. Pos Instagram berbayar selebgram dengan disclosure language akan berpengaruh negatif terhadap preferensi produk. Individu yang melihat pos Instagram dengan disclosure language akan memilih untuk membeli produk lain daripada produk yang diiklankan.

\section{Kemampuan Merekognisi Iklan}

Kemampuan rekognisi iklan adalah salah satu komponen dari kemampuan literasi iklan (Friestad \& Wright, 1994; Malmelin, 2010). Individu yang memiliki kemampuan literasi iklan yang baik akan mampu membedakan konten iklan dengan konten lain, mengevaluasinya, dan memahami maksud pengiklan (Friestad \& Wright, 1994; Malmelin, 2010; Rozendaal, Lapierre, van Reijmersdal, \& Buijzen, 2011). Meski ada studi yang memosisikan kemampuan rekognisi iklan sebagai state (Boerman dkk., 2014; Evans dkk., 2017), penelitian ini memosisikan kemampuan rekognisi iklan sebagai trait. Hal ini didasarkan pada model pengetahuan persuasi yang disampaikan oleh Friestad dan Wright (1994). Menurut keduanya, kemampuan seseorang dalam memahami persuasi tertanam di dalam diri individu dan terus terbentuk sepanjang hidup. Kemampuan ini dipelajari sejak masa kanak-kanak hingga masa sekolah menengah tinggi dan dipengaruhi oleh kondisi orang tua, usia, dan kemampuan kognitif (Edens \& McCormick, 2000; Robertson \& Rossiter, 1974; Vanwesenbeeck, Ponnet, \& Walrave, 2016; Wright dkk., 2005). Individu yang berasal dari tingkat sosioekonomi keluarga yang lebih tinggi juga cenderung menunjukkan kemampuan yang lebih tinggi dalam memahami tujuan iklan karena telah mendapatkan pendidikan yang cukup dari orang tua sejak dini (Edens \& McCormick, 2000).

Berbekal kemampuan literasi iklan, individu akan lebih resisten terhadap persuasi (Friestad \& Wright, 1994). Individu yang memiliki kemampuan literasi tinggi pun akan lebih mudah memahami konten persuasi daripada individu yang memiliki kemampuan literasi rendah sehingga lebih tidak menginginkan produk yang diiklankan (Jae, Delvecchio, \& Cowles, 2008; Robertson \& Rossiter, 1974). Bila melihat konten persuasi bergambar, individu yang memiliki kemampuan literasi rendah akan lebih mudah terpengaruh oleh ajakan dalam konten daripada individu yang memiliki kemampuan literasi tinggi (Jae \& Delvecchio, 2004). Kemampuan literasi iklan individu akan aktif ketika individu berhadapan dengan cue yang menyatakan sebuah konten adalah konten persuasi (Friestad \& Wright, 1994). Dalam konteks iklan tersamar, DL adalah cue tersebut (Campbell, 2013). Peneliti mengajukan hipotesis sebagai berikut.

Hipotesis 2a. Kemampuan merekognisi iklan akan berdampak negatif pada intensi membeli. Semakin tinggi kemampuan rekognisi iklan individu, maka semakin rendah intensi membeli individu terhadap produk yang diiklankan.

Hipotesis 2 b. Kemampuan merekognisi iklan akan berdampak negatif terhadap preferensi produk. Semakin tinggi kemampuan rekognisi iklan individu, maka semakin rendah preferensi individu terhadap produk yang diiklankan.

Hipotesis 3a. Kemampuan rekognisi iklan memperkuat pengaruh negatif disclosure language terhadap intensi membeli. Semakin tinggi kemampuan rekognisi iklan individu, maka semakin kuat pengaruh negatif disclosure language terhadap intensi membeli. 


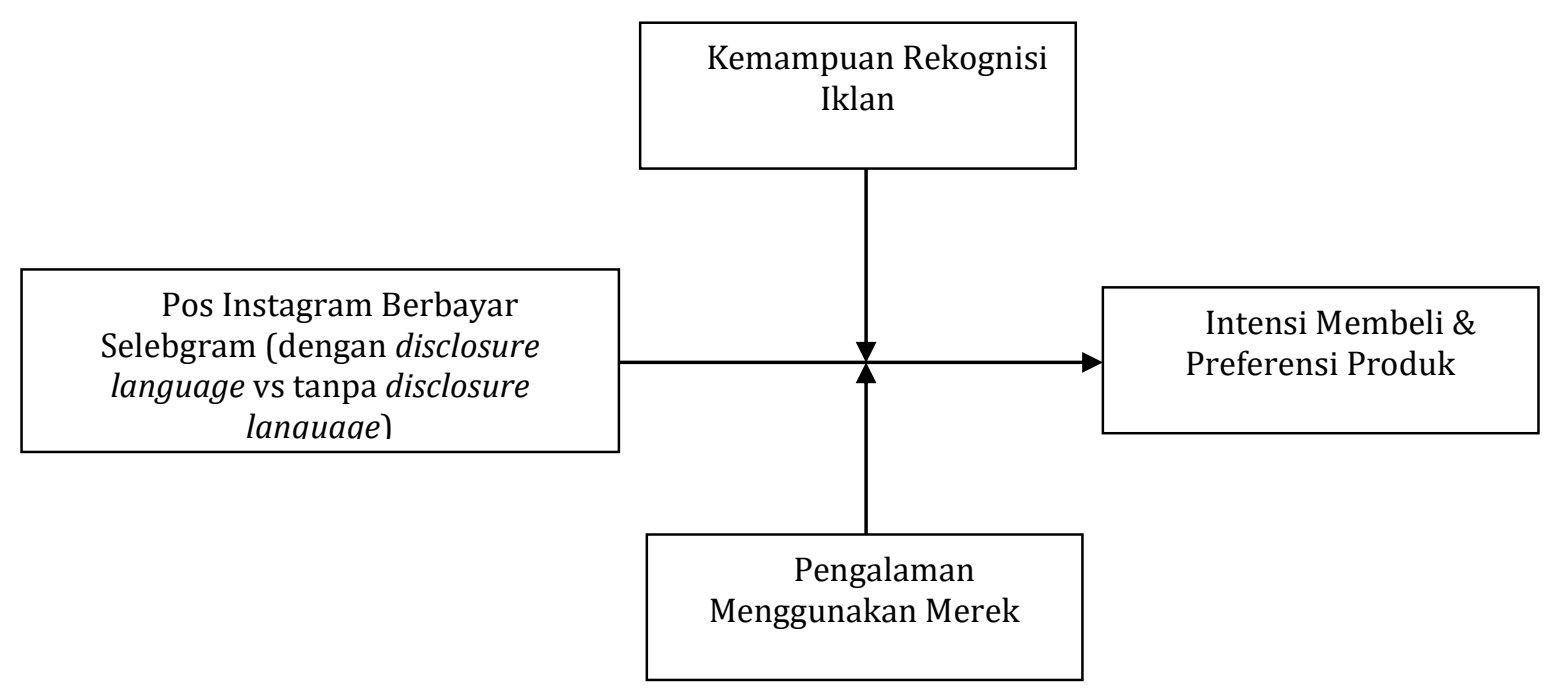

Gambar 1. Model konseptual penelitian

Hipotesis 3b. Kemampuan rekognisi iklan memperkuat pengaruh negatif disclosure language terhadap preferensi produk. Semakin tinggi kemampuan rekognisi iklan individu, maka semakin kuat pengaruh negatif disclosure language terhadap preferensi produk.

\section{Pengalaman Menggunakan Merek}

Dari temuan-temuan sebelumnya, DL kerap ditemukan berpengaruh negatif terhadap intensi membeli (Hwang \& Joeng, 2016; Evans dkk., 2017; van Reijmersdal dkk., 2016; Wojdynski \& Evans, 2015). Namun, boleh jadi ada faktor lain yang dapat mengurangi efek negatif DL, yakni pengalaman menggunakan merek (PMM). Studi Park dan Stoel (2005) menunjukkan bahwa semakin familier individu dengan sebuah merek, entah karena sering muncul dalam iklan atau sudah pernah dicoba secara langsung, semakin tinggi intensi individu untuk membeli produk dari merek tersebut. Hasil ini konsisten dengan studi pendahulunya yang dilakukan oleh Kim dan Sullivan (1998). Studi keduanya menunjukkan bahwa konsumen cenderung lebih ingin mencoba suatu produk baru dari merek yang sebelumnya sudah konsumen kenal. Pengalaman menggunakan merek juga membuat konsumen lebih percaya dan setia terhadap suatu merek hingga membuat konsumen bersedia membeli produk lain dari merek yang sama (Baser, Cintamur, \& Arslan, 2015; Sahin, Zehir, \& Kitapci, 2012).

Kaitannya dengan iklan, konsumen akan lebih mudah mengingat iklan produk dari merek yang pernah ia gunakan ketimbang merek yang tidak pernah ia gunakan (Kent \& Allen, 1994). Efeknya, konsumen akan lebih mudah terpengaruh dengan iklan ini daripada iklan produk yang berasal dari merek lain. Paparan iklan juga terbukti memperkuat sikap positif konsumen terhadap produk baru bila konsumen memiliki PMM (Martinez, Montaner, \&
Pina, 2009). Peneliti mengajukan hipotesis sebagai berikut.

Hipotesis 4a. Pengalaman menggunakan merek berpengaruh positif terhadap intensi membeli. Individu yang pernah menggunakan produk dari merek yang diiklankan akan memiliki intensi membeli yang lebih tinggi daripada individu yang sebelumnya tidak pernah menggunakan produk dari merek yang diiklankan.

Hipotesis 4b. Pengalaman menggunakan merek berpengaruh positif terhadap preferensi individu pada produk yang diiklankan. Individu yang pernah menggunakan produk dari merek yang diiklankan akan memiliki preferensi produk yang lebih tinggi daripada individu yang sebelumnya tidak pernah menggunakan produk dari merek yang diiklankan.

Hipotesis 5a. Pengalaman menggunakan merek melemahkan pengaruh negatif disclosure language terhadap intensi membeli. Semakin tinggi pengalaman menggunakan merek individu, maka pengaruh negatif disclosure language terhadap intensi membeli akan semakin lemah.

Hipotesis 5b. Pengalaman menggunakan merek melemahkan pengaruh negatif disclosure language terhadap intensi membeli. Semakin tinggi pengalaman menggunakan merek individu, maka pengaruh negatif disclosure language terhadap preferensi produk akan semakin lemah.

\section{Metode Penelitian}

Untuk menguji hipotesis, peneliti menyusun sebuah studi eksperimental. Seluruh prosedur, instrumen, dan alat ukur yang digunakan dalam penelitian ini telah disetujui oleh Komite Kaji Etik Fakultas Psikologi Universitas Indonesia pada 21 Januari 2019 dengan nomor 394/Fpsi.Komite Etik/PDP.04.00/2019. 


\section{Partisipan}

Peneliti menargetkan perempuan berusia 1934 tahun sebagai partisipan karena pengguna internet di Indonesia paling banyak berada di rentang usia ini (APJII, 2018). Gender perempuan dipilih sebagai target partisipan karena perempuan lebih rentan terhadap pengaruh iklan daripada laki-laki dan lebih mungkin membeli barang-barang yang diiklankan oleh selebritas favoritnya daripada lakilaki (Djafarova \& Rushworth, 2017). Partisipan direkrut secara daring melalui WhatsApp, milis, Twitter, Facebook, dan Instagram dari tanggal 4 Februari 2019 hingga 27 Februari 2019. Lima partisipan yang beruntung dalam penelitian ini mendapatkan voucher belanja di Blibli.com masingmasing sebesar Rp100.000. Pengumuman pemenang voucher belanja dipublikasikan di situs www.penelitianinstagram.home.blog pada 1 April 2019.

Empat ratus delapan puluh delapan orang yang merupakan pengguna aktif Instagram (membuka Instagram minimal sehari sekali) terlibat sebagai partisipan dalam penelitian ini. Rentang usia partisipan adalah $19-34$ tahun $(M=25 ; S D=3,74)$. Partisipan yang berdomisili di Jabodetabek adalah $41,9 \%$.

Jumlah partisipan yang terlibat melebihi target yang ditentukan peneliti, yakni 250 partisipan berdasarkan perhitungan GPower 3.0 (Faul, Erdfelder, Lang, \& Buchner, 2007) dengan effect size sebesar 0,1 dan power sebesar 0,8.

\section{Desain}

Penelitian ini berdesain eksperimental dengan satu IV yang divariasikan menjadi dua kelompok (dengan DL vs tanpa DL). Partisipan dibagi secara random ke salah satu kondisi. Kemampuan rekognisi iklan dan PMM diperlakukan sebagai moderator.

\section{Prosedur}

Penelitian ini dilakukan secara daring menggunakan platform SurveyMonkey. Partisipan perlu mengklik tautan penelitian untuk bergabung. Ada halaman pengantar di awal yang menjelaskan tujuan penelitian secara singkat. Kemudian, partisipan diminta mengisi lembar persetujuan. Partisipan yang setuju untuk bergabung akan diminta mengklik tautan lain yang mengantarkan partisipan ke halaman sesi eksperimen. Pemisahan tautan ini bertujuan untuk memisahkan data diri partisipan dengan respons partisipan dalam sesi eksperimen. Dengan demikian, respons partisipan tetap anonim.

Saat masuk ke sesi eksperimen, partisipan terlebih dulu mengisi data demografi. Partisipan juga dihadapkan pada tiga pertanyaan yang berfungsi sebagai identifier, yakni pertanyaan mengenai makanan, lagu, dan film favorit. Karena penelitian ini bersifat anonim, identifier inilah yang berfungsi sebagai identitas partisipan. Bila partisipan hendak menarik data dari peneliti, partisipan hanya perlu menyebutkan makanan, lagu, dan film favoritnya secara berurutan sehingga identitas asli partisipan tetap rahasia.

Setelah mengisi data demografi, partisipan ditugaskan ke salah satu kelompok secara random, yakni kelompok BP atau tanpa BP. Randomisasi dilakukan secara otomatis oleh situs Survey Monkey. Partisipan akan melihat stimulus yang disiapkan peneliti berupa pos Instagram. Setelah melihat pos Instagram, partisipan diminta mengisi kuesioner tentang rekognisi iklan, pengalaman menggunakan produk (PMP), dan intensi membeli. Setelah memasukkan data, partisipan dihadapkan pada lembar debriefing dan tautan baru bagi partisipan yang hendak mengikuti undian voucher. Informasi mengenai waktu dan lokasi pengumuman pemenang undian diberikan di akhir kuesioner. Salinan lembar debriefing juga dikirimkan melalui surel. Partisipan yang sewaktu-waktu hendak membatalkan keterlibatannya dapat menghubungi peneliti.

\section{Stimulus}

Stimulus dalam penelitian ini adalah pos Instagram selebgram Rachel Goddard dengan nama akun Instagram @rachgoddard yang sedang menggenggam lipstik Cliquematte merek Make Over. Rachel Goddard dipilih karena saat ini ia merupakan salah satu beauty influencer dengan jumlah pengikut terbanyak di Instagram, yakni sebanyak 656.000 orang. Pertimbangan memilih Rachel Goddard dan lipstik sebagai produk yang diiklankan juga berdasarkan faktor celebrity-brand congruence. Rachel Goddard sebagai seorang beauty influencer yang kerap membuat tutorial tata rias wajah dianggap kongruen dengan produk lipstik yang diiklankan.

Lipstik dipilih sebagai produk yang diiklankan karena merupakan salah satu produk kosmetik terlaris di Indonesia (Snapcart, 2017; Tashandra, 2018). Sementara itu, pemilihan merek Make Over didasarkan pada popularitasnya. Menurut Izazi (2017), lipstik Make Over merupakan produk lipstik paling laris ketiga di BukaLapak setelah Purbasari dan Wardah. Pilihan dijatuhkan pada Make Over dan bukan Purbasari atau Wardah karena di antara ketiganya Make Over-lah yang saat ini sedang gencar melakukan promo di media sosial (Dhetira, 2016). Sementara itu, varian Cliquematte dipilih karena merupakan produk baru dari lini lipstik Make Over (Ellora, 2018). Pemilihan ini bertujuan agar peneliti dapat melihat pengaruh iklan produk baru dari merek yang familier terhadap IM dan PP konsumen.

Pos Instagram asli Rachel Goddard yang sedang menggenggam produk Make Over tidaklah mengandung unsur DL. Foto asli ini peneliti gunakan sebagai stimulus kelompok kontrol (Gambar 2). Untuk kelompok pos Instagram dengan DL, penulis akan memanipulasi pos dengan menambahkan keterangan "paid partnership with makeoverid" di bagian atas foto (Gambar 3 ). 


\section{Instrumen Penelitian}

Berikut ini adalah instrumen yang digunakan dalam penelitian.

Rekognisi iklan. Partisipan diberi satu pernyataan, "Saya menduga pos Instagram yang baru saja saya lihat adalah iklan" dengan pilihan respons 1 (sangat tidak setuju) hingga 7 (sangat setuju). Skor mean partisipan untuk variabel ini adalah $6,05(S D=$ 1,184).

Intensi membeli. Peneliti menggunakan alat ukur intensi membeli yang diadaptasi dari Baker \& Churchill (1977). Koefisien Cronbach's Alpha untuk alat ukur ini adalah 0,809. Alat ukur ini berisi empat item, yakni "saya akan mencoba merek Make Over", "saya akan membeli produk lipstik Cliquematte Make Over jika secara kebetulan melihatnya", "saya akan secara sengaja mencari produk lipstik Cliquematte Make Over di toko online ataupun offline untuk membelinya", dan "saya akan membeli produk lainnya dari merek Make Over". Partisipan diminta merespons dengan salah satu pilihan dari 1 ("Sangat Tidak Setuju") sampai 7 ("Sangat Setuju"). Skor mean partisipan untuk variabel ini adalah 3,866 $(S D=$ 1,150).

Preferensi produk. Peneliti menggunakan cara yang diadaptasi dari penelitian Yang dan RoskosEwoldsen (2007). Peneliti memberikan satu pertanyaan, yakni "Jika Anda diminta memilih voucher belanja produk lipstik sebesar Rp100.000, produk lipstik apa yang Anda inginkan dari kelompok merek di bawah ini?“. Pilihan jawaban mencakup lima merek lipstik, yakni Purbasari, BLP Beauty, Wardah, Mineral Botanica, dan Make Over. Keempat merek lipstik selain Make Over dipilih karena dianggap sebagai merek lipstik lokal yang populer (Handayani, 2016; Tokopedia, 2017). Dengan memilih merek yang popularitasnya hampir sama dengan Make Over, jawaban partisipan diharapkan tidak terganggu dengan unsur popularitas. Respons partisipan yang memilih Make Over akan dikode sebagai 1, sedangkan yang memilih merek lain selain Make Over akan dikode sebagai 0 .

Pengalaman menggunakan merek. Diadopsi dari studi Rahmi, Sekarasih, dan Sjabadhyni (2016), peneliti memberikan tiga pertanyaan kepada partisipan, yakni "apakah Anda menggunakan produk lipstik Cliquematte dari Make Over?”, "apakah Anda menggunakan produk lipstik lainnya dari Make Over?", dan "apakah Anda menggunakan produk kosmetik lainnya dari Make Over?". Partisipan diminta merespons dalam skala likert 0 (tidak pernah) hingga 4 (hampir selalu). Karena penelitian ini fokus pada variabel pengalaman menggunakan merek dan bukan pada pengalaman menggunakan produk, pertanyaan "apakah Anda menggunakan produk lipstik Cliquematte dari Make Over?" digunakan untuk mengeliminasi partisipan. Partisipan yang merespons dari 1-4 untuk pertanyaan ini tidak dilibatkan dalam analisis data. Sementara itu, PMM diukur melalui dua item sisanya. Semakin tinggi skor partisipan berarti semakin tinggi pengalaman partisipan dalam menggunakan merek Make Over. Koefisien Cronbach's Alpha untuk alat ukur ini adalah 0,588. Skor mean partisipan untuk variabel ini adalah 1,247 (SD=1,120).

Pengecekan manipulasi. Manipulasi yang dibuat peneliti dalam penelitian ini adalah pencantuman keterangan paid partnership di bagian atas pos Instagram. Karena itu, peneliti memberi pertanyaan kepada partisipan di akhir studi, yakni "apakah Anda melihat keterangan paid partnership di atas pos?" dengan pilihan jawaban ya atau tidak. Dari 480 partisipan, sebanyak 51 partisipan yang berada di kelompok kontrol (pos Instagram tanpa BP) mengaku melihat keterangan "paid partnership with makeoverid" dalam stimulus yang diberikan peneliti. Padahal, dalam kelompok kontrol, keterangan ini tidak dicantumkan sehingga data partisipan ini tidak diikutsertakan dalam analisis. Di sisi lain, 96 partisipan yang berada dalam kelompok manipulasi (dengan BP) mengaku tidak melihat keterangan "paid partnership with makeoverid" dalam stimulus yang diberikan peneliti sehingga partisipan dikecualikan dalam analisis data. Peneliti juga mengeliminasi partisipan yang pernah menggunakan lipstik Make Over Cliquematte yakni sebanyak 29 partisipan. Total sebanyak 312 partisipan dilibatkan dalam analisis.

\section{Teknik Analisis}

Untuk menganalisis data penelitian dengan IM sebagai DV, penulis akan menggunakan model 2 Hayes' PROCESS version 3.0 untuk IBM SPSS dengan 5.000 bootstrap samples (Hayes, 2018). Sementara itu, untuk menganalisis data penelitian dengan PP sebagai DV, penulis akan melakukan regresi logistik untuk membandingkan pengaruh IV terhadap preferensi individu dalam memilih produk Make Over dibandingkan produk lainnya.

Gambar. Berikut ini adalah stimulus yang peneliti gunakan sebagai manipulasi.

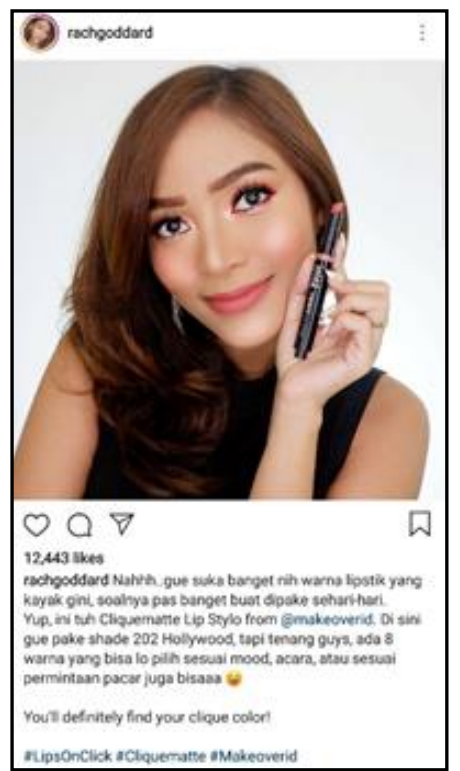

Gambar 2. Stimulus pos Instagram untuk kelompok tanpa DL 


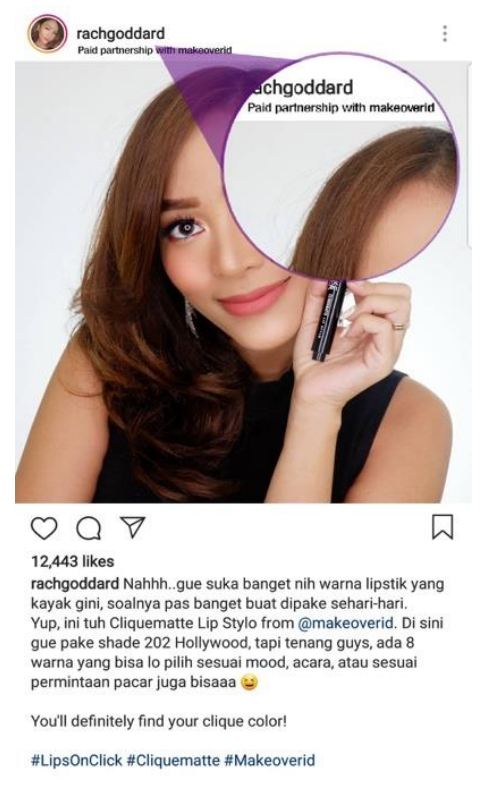

Gambar 3. Stimulus pos Instagram untuk kelompok dengan DL

\section{Hasil Penelitian}

Ada dua variabel dependen yang diukur dalam penelitian ini, yakni intensi membeli dan preferensi produk. Hasil korelasi seluruh variabel dapat dilihat dalam Tabel 1.

\section{Intensi Membeli}

Pengaruh DL, rekognisi iklan, dan PMP terhadap IM dianalisis menggunakan model 2 Hayes' PROCESS version 3.0 untuk IBM SPSS. Effect size yang diperoleh dari model ini sebesar 0,140 atau dapat dikategorikan sebagai effect size kecil (Cohen, 1988). Berdasarkan hasil analisis data yang tercantum dalam Tabel 2, DL pada pos Instagram berpengaruh negatif terhadap IM secara signifikan (H1a) $(b=$ $1,618, \mathrm{SE}=0,662, p=0,015,95 \%$ CI $[-2,921,-0,314])$. Hasil ini menandakan bahwa keterangan "paid partnership" dalam pos Instagram berbayar dapat melemahkan IM individu terhadap produk baru yang diiklankan. Hipotesis 1a diterima.

Sementara itu, kemampuan individu merekognisi iklan tidak terbukti berpengaruh signifikan terhadap IM (H2a) (b=-0,070, SE =0,068, $p=0,307,95 \%$ CI $[-0,204,0,064]) ;$ H2a ditolak. Namun, terdapat interaksi yang signifikan antara DL dan kemampuan rekognisi iklan terhadap IM (H3a) $(b=0,249, S E=0,103, p=0,016,95 \%$ CI $[0,046$, $0,452])$. Koefisien positif pada $b$ menunjukkan bahwa kemampuan rekognisi iklan individu justru dapat melemahkan pengaruh negatif DL terhadap IM. Karena arah moderasinya berbanding terbalik dengan hipotesis, H3a ditolak.

Sementara itu, PMM terbukti berpengaruh positif secara signifikan terhadap intensi membeli (H4a) (b=0,349, SE=0,071, $p=0,000,95 \%$ CI $[0,209$,
0,488]). Hasil ini menunjukkan bahwa semakin sering individu menggunakan produk Make Over, maka semakin tinggi IM individu membeli produk baru dari Make Over; H4a diterima. Namun, interaksi antara DL dan PMM tidak ditemukan berpengaruh signifikan terhadap intensi membeli ( $\mathrm{H} 5 \mathrm{a})(\mathrm{b}=0,127, \mathrm{SE}=0,110$, $p=0,247,95 \%$ CI $[-0,089,0,343])$; H5a ditolak. Pengalaman menggunakan merek berdampak positif terhadap IM produk yang diiklankan, terlepas dari ada atau tidaknya keberadaan DL dalam iklan tersebut.

\section{Preferensi Produk}

Peneliti menggunakan analisis regresi logistik untuk menguji preferensi partisipan terhadap produk yang diiklankan: apakah partisipan lebih memilih produk yang diiklankan untuk dibeli dibandingkan produk lainnya? Partisipan yang memilih produk lipstik Make Over diberi kode "1" sedangkan yang memilih produk selain Make Over diberi kode "0."

Berdasarkan hasil analisis dalam Tabel 3, pos Instagram dengan DL tidak terbukti berpengaruh terhadap preferensi individu pada produk Make Over $(\mathrm{H} 1 \mathrm{~b})(\mathrm{B}=3,003, \mathrm{SE}=2,035, p=0,140)$; H1b ditolak. Kemampuan merekognisi iklan juga tidak terbukti berpengaruh terhadap PP (H2b) $(B=0,258, S E=$ 0,189, $p=0,171$ ); H2b ditolak. Namun, interaksi antara DL dan kemampuan rekognisi iklan berpengaruh negatif signifikan marjinal terhadap PP (H3b) $(\mathrm{B}=-0,560, \mathrm{SE}=0,319, p=0,079)$. Semakin tinggi kemampuan rekognisi iklan individu, maka semakin lemah pengaruh positif DL terhadap PP. Hipotesis $3 \mathrm{~b}$ diterima. Predicted probability untuk interaksi ini adalah 0,363. Artinya, pada individu dengan skor kemampuan rekognisi iklan yang lebih tinggi, potensi untuk memilih produk Make Over daripada produk merek lainnya hanya sebesar 0,363 kali.

Sementara itu, PMM ditemukan berpengaruh secara positif terhadap preferensi produk $(\mathrm{H} 4 \mathrm{~b})(\mathrm{B}=$ $3,051, \mathrm{SE}=0,432, \quad p=0,000$ ) dengan predicted probability sebesar 0,955. Artinya, individu yang pernah menggunakan produk bermerek Make Over sebelumnya berpotensi sebesar 0,955 kali untuk memilih produk merek Make Over kembali ketimbang produk merek lainnya. Hipotesis 4b diterima. Namun, interaksi antara PMM dan keberadaan DL dalam pos Instagram berbayar tidak terbukti mempengaruhi preferensi individu terhadap produk yang diiklankan ( $\mathrm{H} 5 \mathrm{~b})(\mathrm{B}=0,232, \mathrm{SE}=0,775$, $p=0,765$ ); H5b ditolak. Artinya, bila individu pernah menggunakan sebuah produk dari suatu merek, individu akan cenderung memilih produk atau merek itu kembali di masa mendatang, terlepas dari ada atau tidaknya DL dalam konten iklan produk tersebut.

Gambar. Interaksi DL dan rekognisi iklan terhadap intensi membeli dapat dilihat pada Gambar 4. 
Tabel 1. Korelasi Antarvariabel

\begin{tabular}{|c|c|c|c|c|c|c|}
\hline No & Variabel & 1 & 2 & 3 & 4 & 5 \\
\hline 1 & DL & - & & & & \\
\hline 2 & Rekognisi Iklan & $-0,016$ & - & & & \\
\hline 3 & PMM & $-0,011$ & $-0,079$ & - & & \\
\hline 4 & Intensi Membeli & 0,014 & 0,006 & $0,378^{* *}$ & - & \\
\hline 5 & Preferensi Produk & $-0,048$ & $-0,031$ & $0,750 * *$ & $0,325^{* *}$ & - \\
\hline
\end{tabular}

Ket: ${ }^{+}<0,1,{ }^{*}<0,05,{ }^{* *}<0,01, \mathrm{DL}=$ disclosure language, $\mathrm{PMM}=$ pengalaman menggunakan merek

Tabel 2. Pengaruh Disclosure Language, Kemampuan Merekognisi Iklan, dan Pengalaman Menggunakan Merek terhadap Intensi Membeli

\begin{tabular}{|c|c|c|c|c|c|c|}
\hline & $\mathbf{b}$ & SE & $\mathbf{t}$ & $\mathbf{p}$ & LLCI & ULCI \\
\hline DL & $-1,618^{*}$ & 0,662 & $\begin{array}{c}- \\
2,442\end{array}$ & 0,015 & $\begin{array}{c}- \\
2,921\end{array}$ & $\begin{array}{c}- \\
0,314\end{array}$ \\
\hline Rekognisi Iklan & $-0,070$ & 0,068 & $\begin{array}{c}- \\
1,024\end{array}$ & 0,307 & 0,204 & 0,064 \\
\hline PMM & $0,349^{* *}$ & 0,071 & 4,923 & 0,000 & 0,209 & 0,488 \\
\hline DL x Rekognisi Iklan & $0,249^{*}$ & 0,103 & 2,416 & 0,016 & 0,046 & 0,452 \\
\hline DL x PMM & 0,127 & 0,110 & 1,159 & 0,247 & $\begin{array}{c}- \\
0,089\end{array}$ & 0,343 \\
\hline constant & $3,839^{* *}$ & 0,431 & 8,911 & 0,000 & 2,991 & 4,687 \\
\hline
\end{tabular}

Ket: ${ }^{+}<0,1,{ }^{*}<0,05,{ }^{* *}<0,01, \mathrm{DL}=$ disclosure language, $\mathrm{PMM}=$ pengalaman menggunakan merek

Tabel 3. Pengaruh Disclosure Language, Kemampuan Merekognisi Iklan, dan Pengalaman Menggunakan Merek terhadap Preferensi Produk

\begin{tabular}{lccccc}
\hline & B & S.E. & p. & $\begin{array}{c}\text { Odd- } \\
\text { Ratio }\end{array}$ & $\begin{array}{c}\text { Predicted } \\
\text { Probabilit } \\
\text { y }\end{array}$ \\
\hline DL & 3,003 & 2,035 & 0,140 & 20,151 & 0,952 \\
Rekognisi Iklan & 0,258 & 0,189 & 0,171 & 1,295 & 0,564 \\
PMM & $3,051^{* *}$ & 0,432 & 0,000 & 21,130 & 0,954 \\
DL x Rekognisi Iklan & $-0,560^{+}$ & 0,319 & 0,079 & 0,571 & 0,363 \\
DL x PMM & 0,232 & 0,775 & 0,765 & 1,261 & 0,558 \\
constant & $-4,785^{* *}$ & 1,288 & 0,000 & 0,008 & 0,008 \\
\hline
\end{tabular}

Ket: ${ }^{+}<0,1,{ }^{*}<0,05,{ }^{* *}<0,01, \mathrm{DL}=$ disclosure language, $\mathrm{PMM}=$ pengalaman menggunakan merek 


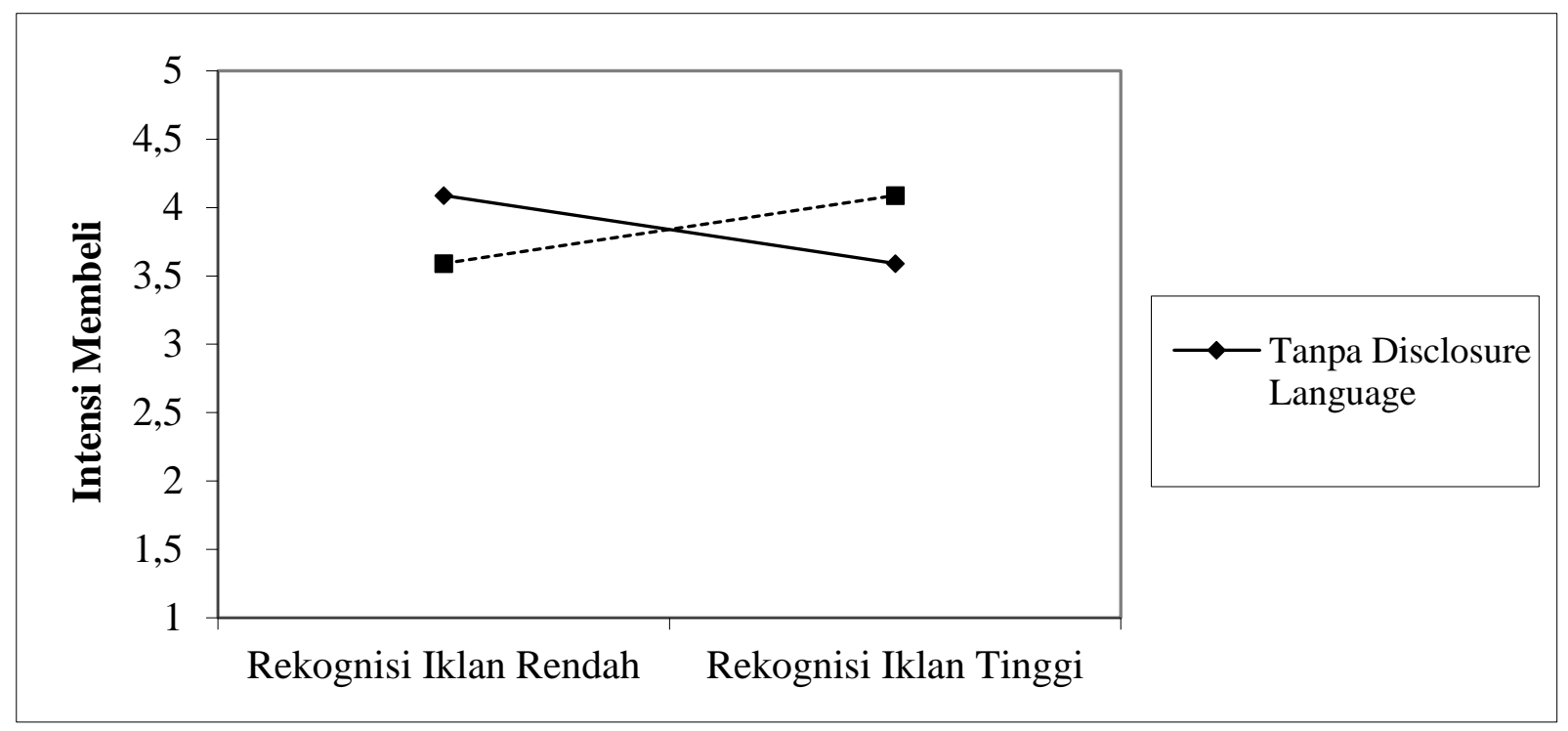

Gambar 4. Interaksi antara disclosure language dan kemampuan merekognisi iklan terhadap intensi membeli

\section{Diskusi}

Sesuai dengan hipotesis, penelitian ini menunjukkan bahwa pos iklan di Instagram yang mengandung DL berupa keterangan paid partnership mampu menurunkan intensi membeli individu. Hasil ini konsisten dengan penelitian sebelumnya (Janssen, Fennis, \& Pruyn, 2016; van Reijmersdal et al., 2016; Wojdynski \& Evans, 2015). Ini berarti aturan baru mengenai DL yang diterapkan Instagram efektif untuk melindungi konsumen dari pengaruh konten persuasi tersamar di Instagram.

Namun, tidak sesuai yang diprediksi, keberadaan DL justru menjadi bumerang bagi individu yang memiliki kemampuan rekognisi iklan tinggi. Pasalnya, efektivitas DL dalam mengurangi intensi membeli justru melemah pada individu dengan karakteristik seperti ini. Temuan ini mendukung pernyataan Wright et al. (2005). Wright dan kolega (2005) menyebutkan bahwa individu yang memiliki kemampuan mengenali iklan akan cenderung skeptis terhadap konten yang diduga iklan dan coba mencari desepsi yang tersembunyi dalam iklan. Namun, ketika konten iklan sengaja diungkapkan, level skeptisisme konsumen justru menurun sehingga tidak lagi waspada terhadap desepsi iklan dan akhirnya terpengaruh untuk membeli produk (Wright et al., 2005).

Efek sebaliknya terjadi pada preferensi produk. Bila kemampuan rekognisi iklan dapat meningkatkan intensi membeli pada individu yang melihat iklan dengan DL, rekognisi iklan justru dapat melemahkan preferensi produk pada individu yang melihat iklan dengan DL. Artinya, setelah melihat iklan dengan DL, individu dengan kemampuan rekognisi iklan tinggi masih mungkin memiliki intensi membeli yang tinggi terhadap produk yang diiklankan. Namun, saat diminta memilih produk yang diiklankan atau produk dari merek lain, individu dengan kemampuan rekognisi iklan tinggi lebih memilih produk dari merek lain.

Perbedaan efek interaksi DL dan rekognisi iklan terhadap intensi membeli dan preferensi produk dapat terjadi karena keduanya (intensi membeli dan preferensi produk) terjadi atas mekanisme yang berbeda. Menurut Sirgy (2015), preferensi individu terhadap sebuah produk tercipta karena individu ingin mewujudkan diri idealnya dengan memiliki suatu produk, sedangkan intensi individu untuk membeli suatu produk terjadi karena produk dianggap sesuai dengan kondisi dan kebutuhan aktual individu. Preferensi produk terjadi ketika individu menganggap sebuah produk sesuai dengan citra diri idealnya, tetapi tidak demikian dengan intensi membeli (Sirgy, 2015). Untuk tahu apakah sebuah produk sesuai dengan citra dirinya atau tidak, konsumen kerap melihat figur selebritas yang menggunakan produk (Lu et al., 2014).

Tanpa keberadaan DL dalam konten persuasi, konsumen akan menganggap selebritas benar-benar menyukai dan merekomendasikan suatu produk (Lu et al., 2014; Silvera \& Austad, 2003). Konsumen pun akan ikut menyukai produk karena ingin memiliki citra diri yang sama dengan selebritas yang menggunakan produk (Djafarova \& Rushworth, 2017). Namun, ketika DL muncul dalam konten persuasi dan konsumen memiliki kemampuan rekognisi iklan yang tinggi, konsumen akan sadar bahwa selebritas tidak benar-benar menyukai dan merepresentasikan produk sehingga konsumen merasa citra diri ideal yang ingin ia capai tidak terwakili oleh sosok selebritas tersebut (Lu et al., 2014). Dampaknya, sesuai dengan hasil yang ditunjukkan penelitian ini, preferensi konsumen terhadap produk akan melemah. Tidak terjadi dampak yang sama pada intensi membeli karena intensi membeli tidak terkait dengan citra diri ideal yang hendak dicapai konsumen melalui kepemilikan suatu produk (Sirgy, 2015). 
Selain pengaruh DL dan rekognisi iklan terhadap intensi membeli dan preferensi produk, hasil penelitian ini juga menunjukkan bahwa PMM terbukti berpengaruh positif secara signifikan, baik terhadap intensi membeli dan preferensi produk. Artinya, bila seseorang sudah pernah menggunakan produk dari suatu merek, keinginannya untuk membeli dan memilih produk baru dari merek yang sama akan meningkat. Hasil ini sejalan dengan penelitian sebelumnya (Park \& Stoel, 2005; Baser et al., 2015; Sahin et al., 2012) yang menunjukkan bahwa pengalaman individu dalam menggunakan suatu merek berpengaruh positif terhadap minat individu untuk membeli produk baru dari merek yang sama. Pengaruh PMM terhadap intensi membeli dan preferensi produk pun terlepas dari ada atau tidaknya DL dalam iklan.

Hasil penelitian ini memberi masukan bagi studi psikologi di ranah konsumen bahwa keberadaan DL dalam konten persuasi tidak senantiasa menurunkan intensi membeli. Intensi membeli konsumen setelah melihat konten persuasi dengan DL dapat menguat bila konsumen memiliki kemampuan rekognisi iklan yang tinggi. Namun, preferensi konsumen terhadap produk memang dapat melemah, terutama pada konten persuasi yang menggunakan selebritas.

\section{Kesimpulan}

Kemampuan literasi iklan dan keberadaan DL dalam iklan telah lama dipercaya mampu melindungi konsumen dari pengaruh iklan (Evans et al., 2017; Friestad \& Wright, 1994; van Reijmersdal et al., 2016; Robertson \& Rossiter, 1974). Hasil penelitian ini mendukung temuan tersebut. Keberadaan DL memang signifikan melemahkan intensi membeli konsumen. Namun, kemampuan rekognisi iklan tinggi hanya mampu melemahkan preferensi produk, tetapi justru meningkatkan intensi membeli setelah individu melihat konten persuasi dengan DL. Hal lain yang ditunjukkan oleh penelitian ini adalah PMM berpengaruh positif terhadap intensi membeli maupun preferensi produk, terlepas dari ada atau tidaknya DL dalam konten persuasi.

Keterbatasan dan saran. Keterbatasan penelitian ini terletak pada stimulusnya yang menggunakan satu model iklan saja, yakni pos Instagram selebgram. Dengan demikian, belum diketahui apakah hasil temuan penelitian ini juga berlaku pada bentuk iklan yang lain atau terbatas pada iklan berbentuk pos Instagram saja. Penelitian selanjutnya perlu meneliti efek DL terhadap intensi membeli dan preferensi produk dalam bentuk iklan yang lain, seperti pos blog ataupun pos Twitter. Penelitian selanjutnya juga perlu mempertimbangkan faktor kongruensi antara produk dalam iklan dan citra diri ideal individu karena preferensi produk sangat terkait dengan hal ini. Peneliti juga menyarankan penelitian selanjutnya untuk menggunakan atau mengonstruksi alat ukur
PMM lain karena reliabilitas alat ukur PMM dalam penelitian ini tidak cukup baik.

\section{Ucapan Terima Kasih}

Penelitian ini didanai oleh Lembaga Pengelola Dana Pendidikan Kementerian Keuangan Republik Indonesia. Namun, hasil penelitian ini tetap independen. Tidak ada konflik kepentingan dalam penelitian ini.

\section{Daftar Pustaka}

Amornpashara, N., Rompho, N., \& Phadoongsitthi, M. (2015). A study of the relationship between using Instagram and purchase intention. Journal for Global Business Advancement, 8(3), 354-370.

Asosiasi Penyelenggara Jasa Internet Indonesia. (2017). Penetrasi dan perilaku pengguna internet Indonesia: Survei 2017. Retrieved from https://web.kominfo.go.id/

Baker, M. J., \& Churchill Jr, G. A. (1977). The impact of physically attractive models on advertising evaluations. Journal of Marketing research, 14(4), p. 538-555. DOI: 10.2307/3151194

Başer, İ. U., Cintamür, İ. G., \& Arslan, F. M. (2015). Examining the effect of brand experience on consumer satisfaction, brand trust and brand loyalty. Marmara University Journal of Economic \& Administrative Sciences, 37(2), 101-128.

Boerman, S. C., Van Reijmersdal, E. A., \& Neijens, P. C. (2014). Effects of sponsorship disclosure timing on the processing of sponsored content: A study on the effectiveness of European disclosure regulations. Psychology \& Marketing, 31(3), 214-224. https://doi.org/10.1002/mar.20688

Brehm, J. W. (1993). "Control, its loss, and psychological reactance". In: Weary G., Gleicher F., Marsh K.L. (eds) Control Motivation and Social Cognition. NY: Springer.

Campbell, M. C., Mohr, G. S., \& Verlegh, P. W. (2013). Can disclosures lead consumers to resist covert persuasion? The important roles of disclosure timing and type of response. Journal of Consumer Psychology, 23(4), 483-495. https://doi.org/10.1016/j.jcps.2012.10.012

Campbell, M. C., Mohr, G. S., \& Verlegh, P. W. (2013). Can disclosures lead consumers to resist covert persuasion? The important roles of disclosure timing and type of response. Journal of Consumer Psychology, 23(4), 483-495.

Chae, J. (2017). Explaining females' envy toward social media influencers. Media Psychology, 21(2), p. 246-262. https://doi.org/10.1080/15213269.2017.132 8312 
Cohen, J. (1988). Statistical Power Analysis for the Behavioral Sciences (2nd ed.). NJ: Lawrence Erlbaum Associates.

De Jans, S., Cauberghe, V., \& Hudders, L. (2018). How an advertising disclosure alerts young adolescents to sponsored vlogs: The moderating role of a peer-based advertising literacy intervention through an informational vlog. Journal of Advertising, 47(4), 309-325.

De Veirman, M., \& Hudders, L. (2019). Disclosing sponsored influencer posts: The role of material connection with a brand and message sidedness. In ICA 2019.

Dhetira, A. (2016, October 27). MakeOver penetrasi pasar melalui ajang fashion show. SWA. Retrieved from https://swa.co.id

Djafarova, E., \& Rushworth, C. (2017). Exploring the credibility of online celebrities' Instagram profiles in influencing the purchase decisions of young female users. Computers in Human Behavior, 68, p. 1-7. https://doi.org/10.1016/j.chb.2016.11.009

Edens, K. M., \& McCormick, C. B. (2000). How do adolescents process advertisements? The influence of ad characteristics, processing objective, and gender. Contemporary Educational Psychology, 25(4), 450-463. https://doi.org/10.1006/ceps.1999.1031

Ellora, D. (2018, Juni 13). Review: Make Over Cliquematte Lip Stylo, hadirkan lipstik format baru yang formulanya nyaman di bibir. Sociolla. Retrieved from https://journal.sociolla.com

Evans, N. J., Phua, J., Lim, J., \& Jun, H. (2017). Disclosing instagram influencer advertising: The effects of disclosure language on advertising recognition, attitudes, and behavioral intent. Journal of Interactive Advertising, 17(2), p. 138149.

https://doi.org/10.1080/15252019.2017.136 6885

Fang, L., \& Jiang, Y. (2015). Persuasiveness of celebrity endorsed advertising and a new model for celebrity endorser selection. Journal of Asian Business Strategy, 5(8), 153-173.

Faul, F., Erdfelder, E., Lang, A.-G., \& Buchner, A. (2007). G*Power 3: A flexible statistical power analysis program for the social, behavioral, and biomedical sciences. Behavior Research Methods, 39, p. 175-191.

Friestad, M., \& Wright, P. (1994). The persuasion knowledge model: How people cope with persuasion attempts. Journal of consumer research, 21(1), 1-31. https://doi.org/10.1086/209380

Handayani, A. (2016, November 20). 5 rekomedasi lipstik lokal dengan kualitas internasional yang wajib kamu miliki. Beautynesia. Retrieved from http://beautynesia.id/9438

Hayes, A. F. (2018). Introduction to mediation, moderation, and conditional process analysis. (2nd Ed.). New York: The Guilford Press.
Hobbs, R., \& Frost, R. (2003). Measuring the acquisition of media-literacy skills. Reading Research Quarterly, 38(3), 330-355. https://doi.org/10.1598/RRQ.38.3.2

Hwang, Y., \& Jeong, S. H. (2016). This is a sponsored blog post, but all opinions are my own": The effects of sponsorship disclosure on responses to sponsored blog posts. Computers in Human Behavior, 62, 528-535. https://doi.org/10.1016/j.chb.2016.04.026

Instagram (n.d.). Konten bermerek di Instagram. Instagram. Retrieved from https://help.instagram.com/1169470423015 56

Izazi, R. (2017, Desember 31). Ini 5 lipstik paling laris sepanjang tahun 2017, mana favorit kamu? Buka Review. Retrieved from https://review.bukalapak.com

Jae, H., \& DelVecchio, D. (2004). Decision making by low-literacy consumers in the presence of point-of-purchase information. Journal of Consumer Affairs, 38(2), 342-354. https://doi.org/10.1111/j.17456606.2004.tb00873.x

Jae, H., Delvecchio, D. S., \& Cowles, D. (2008). Picturetext incongruency in print advertisements among low-and high-literacy consumers. Journal of Consumer Affairs, 42(3), 439-451. https://doi.org/10.1111/j.17456606.2008.00117.x

Jamal, A., \& Goode, M. M. (2001). Consumers and brands: A study of the impact of self-image congruence on brand preference and satisfaction. Marketing Intelligence \& Planning, 19(7), 482-492.

Janssen, L., Fennis, B. M., \& Pruyn, A. T. H. (2010). Forewarned is forearmed: Conserving selfcontrol strength to resist social influence. Journal of experimental social psychology, 46(6), 911-921. https://doi.org/10.1016/j.jesp.2010.06.008

Kent, R. J., \& Allen, C. T. (1994). Competitive interference effects in consumer memory for advertising: The role of brand familiarity. Journal of Marketing, 58(3), 97-105.

Kim, B. D., \& Sullivan, M. W. (1998). The effect of parent brand experience on line extension trial and repeat purchase. Marketing Letters, 9(2), 181-193.

Lu, L. C., Chang, W. P., \& Chang, H. H. (2014). Consumer attitudes toward blogger's sponsored recommendations and purchase intention: The effect of sponsorship type, product type, and brand awareness. Computers in Human Behavior, 34, 258-266

Malmelin, N. (2010). What is advertising literacy? Exploring the dimensions of advertising literacy. Journal of Visual Literacy, 29(2), 129142.

https://doi.org/10.1080/23796529.2010.116 74677 
Martínez, E., Montaner, T., \& Pina, J. M. (2009). Brand extension feedback: The role of advertising. Journal of Business Research, 62(3), 305-313.

Miller, C. H., Lane, L. T., Deatrick, L. M., Young, A. M., \& Potts, K. A. (2007). Psychological reactance and promotional health messages: The effects of controlling language, lexical concreteness, and the restoration of freedom. Human Communication Research, 33(2), 219-240. https://doi.org/10.1111/j.14682958.2007.00297.x

Pappas, I. O., G. Pateli, A., N. Giannakos, M., \& Chrissikopoulos, V. (2014). Moderating effects of online shopping experience on customer satisfaction and repurchase intentions. International Journal of Retail \& Distribution Management, 42(3), 187-204. https://doi.org/10.1108/IJRDM-03-20120034

Park, J., \& Stoel, L. (2005). Effect of brand familiarity, experience and information on online apparel purchase. International Journal of Retail \& Distribution Management, 33(2), p. 148-160. https://doi.org/10.1108/0959055051058147 6

Pornpitakpan, C. (2003). Validation of the celebrity endorsers' credibility scale: Evidence from Asians. Journal of Marketing Management, 19(1-2), 179-195.

Priambada, A. (2016, September 22). Survei DailySocial: Iklan Facebook dan Instagram berperan besar dalam mendorong keputusan berbelanja online di Indonesia. Daily Social. Retrieved from https://dailysocial.id/

Quick, B. L., \& Stephenson, M. T. (2007). Further evidence that psychological reactance can be modeled as a combination of anger and negative cognitions. Communication Research, 34(3), p. 255-276. https://doi.org/10.1177/0093650207300427

Rahmi, Y., Sekarasih, L., \& Sjabadhyni, B. (2016). The influence of beauty vlog on perceived source credibility and purchase intention. Makara Hubs-Asia, 20(2), p. 13-23. DOI: 10.7454/mssh.v21i1.3496

Robertson, T. S., \& Rossiter, J. R. (1974). Children and commercial persuasion: An attribution theory analysis. Journal of Consumer Research, 1(1), 13-20. https://doi.org/10.1086/208577

Rozendaal, E., Lapierre, M. A., Van Reijmersdal, E. A., \& Buijzen, M. (2011). Reconsidering advertising literacy as a defense against advertising effects. Media Psychology, 14(4), 333-354.

https://doi.org/10.1080/15213269.2011.620 540

Sahin, A., Zehir, C., \& Kitapçı, H. (2011). The effects of brand experiences, trust and satisfaction on building brand loyalty; An empirical research on global brands. Procedia-Social and Behavioral Sciences, 24, 1288-1301.
Silvera, D. H., \& Austad, B. (2003). Factors predicting the effectiveness of celebrity endorsement advertisements. European Journal of marketing, 38(11/12), 1509-1526.

Sirgy, M. J. (2015). The self-concept in relation to product preference and purchase intention. In Venkatakrishna V. B. (ed) Marketing Horizons: A 1980's Perspective (pp. 350-354). Texas: Springer.

Snapcart. (2017, Mei 24). Menganalisis konsumsi kosmetik perempuan millennials Indonesia. Retrieved from https://snapcartbrasil.com

Spangler, T. (2017, June 14). Instagram will add 'paid partnership' tag to sponsored posts, after FTC's warnings to celebrity users. Variety. Retrieved from https://variety.com

Spears, N., \& Singh, S. N. (2004). Measuring attitude toward the brand and purchase intentions. Journal of Current Issues \& Research in Advertising, 26(2), 53-66.

Tashandra, N. (2018, September 10). "Kategori 'beauty' favorit di Shopee, lipstik enggak ada habisnya". Kompas.com. Retrieved from https://lifestyle.kompas.com

Tokopedia (2017, Oktober 3). 35 merk lipstik lokal yang boleh kamu coba. Tokopedia. Retrieved from

https://www.tokopedia.com/blog/merkkosmetik-lipstik-lokal-indonesia/

Van Reijmersdal, E. A., Fransen, M. L., van Noort, G., Opree, S. J., Vandeberg, L., Reusch, S., ... \& Boerman, S. C. (2016). Effects of disclosing sponsored content in blogs: How the use of resistance strategies mediates effects on persuasion. American Behavioral Scientist, 60(12),

1458-1474. https://doi.org/10.1177/0002764216660141

Vanwesenbeeck, I., Walrave, M., \& Ponnet, K. (2016). Young adolescents and advertising on social network games: A structural equation model of perceived parental media mediation, advertising literacy, and behavioral intention. Journal of Advertising, 45(2), 183-197. https://doi.org/10.1080/00913367.2015.112 3125

Wojdynski, B. W., \& Evans, N. J. (2016). Going native: Effects of disclosure position and language on the recognition and evaluation of online native advertising. Journal of Advertising, 45(2), 157168. https://doi.org/10.1080/00913367.2015.111 5380

Wright, P., Friestad, M., \& Boush, D. M. (2005). The development of marketplace persuasion knowledge in children, adolescents, and young adults. Journal of Public Policy \& Marketing, 24(2),

222-233. https://doi.org/10.1509/jppm.2005.24.2.222

Yang, M., \& Roskos-Ewoldsen, D. R. (2007). The effectiveness of brand placements in the movies: Levels of placements, explicit and implicit memory, and brand-choice behavior. 
Journal of Communication, 57(3), p. 469-489. https://doi.org/10.1111/j.14602466.2007.00353.x
Yayasan Lembaga Konsumen Indonesia. (2015, April). Undang-undang Republik Indonesia nomor 8 tahun 1999. YLKI. Retrieved from https://ylki.or.id 